\title{
UČENJE FRANCUSKOG JEZIKA (L2) I MEĐUJEZIK - STUDIJA SLUČAJA
}

Sonja Špadijer, Univerzitet Crne Gore, Filološki fakultet, sonjas@ucg.ac.me

Originalni naučni rad

DOI: 10.31902/fll.34.2021.16

UDK: 811.133.1:378

Apstrakt: Tokom procesa učenja L2, studenti stvaraju sistem apstraktnih jezičkih pravila koja omogućavaju razumijevanje i produkciju na L2. Taj sistem pravila smatra se mentalnom gramatikom (Elis 1997, 33) i nosi naziv međujezik (Interlanguage) (Selinker 1972; 1975). Međujezik predstavlja fazu u procesu učenja L2 koja pomaže učenicima da mentalno restrukturiraju nova znanja, nove oblike, strukture i funkcije koje upravo uče. Jezik kojim se služe studenti nije samo rezultat razlika između jezika koje već znaju i jezika koji uče, već je riječ o cjelovitom i potpunom jezičkom sistemu koji ima sopstvena pravila. Strukture koje nastaju u okviru međujezika nijesu proizvoljne.

U ovom radu, moj cilj je da opišem karakteristike jezika (L2) kojim govore studenti prve i završne godine studija francuskog jezika i književnosti, da objasnim šta to govori o prirodi njihovog znanja i na koji način se njihov međujezik razlikuje od norme standardnog francuskog jezika.

Da bih postigla zadati cilj, u okviru studije slučaja, proučavaću kako se kod studenata razvija sposobnost da produkuju određene gramatičke strukture. Opisaću uočene greške koje studenti prave, objasniću ih, procijeniti po metodologiji Teorije usvanja L2 - SLA (Elis 1997, 16-23).

$\mathrm{Na}$ osnovu elemenata koji karakterišu međujezik studenata prve godine i međujezik studenata četvrte godine, ustanoviću kako su se razvijali.

Rezultati istraživanja imaće primjenu u redefinisanju nastavnih ciljeva $\mathrm{i}$ aktivnosti.

Ključne riječi: učenje L2, analiza grešaka, međujezik, međujezički kontinuum, greške vs. Omaške.

\section{Uvod}

Kako izvorni govornici jednog od BCHS jezika uče francuski kao ciljni jezik (L2)? Na koji način možemo da dođemo do odgovora na ovo pitanje? Smatramo da nam u tome može pomoći proučavanje njihovog međujezika.

Ovaj rad inspirisan je potrebom usklađivanja nastave francuskog jezika kao L2 sa rezultatima istraživanja koja se bave svojstvima međujezika kojim govore studenti. $U$ radu ću najprije navesti cilj i metodologiju istraživanja. Nakon toga, pojasniću osnovne koncepte 
teorije učenja L2, kontrastivne analize, analize grešaka i međujezika. U trećem dijelu izložiću studiju slučaja i rezultate istraživanja.

Opisaću karakteristike francuskog jezika kao ciljnog jezika (target language) $^{1}$ odnosno drugog jezika L2 kojim govore studenti prve i završne godine francuskog jezika i književnosti na Filološkom fakultetu u Nikšiću. Pokušaću da opišem promjene u upotrebi L2 do kojih dolazi tokom određenog vremenskog perioda i da odgovorim na pitanje o tome šta to govori o prirodi njihovog znanja. Na osnovu analize razlika $u$ upotrebi jezika studenata prve godine i četvrte godine izdvojiću elemente po kojima se njihov francuski jezik razlikuje od norme standardnog francuskog jezika koji koriste izvorni govornici a koju težimo da savladamo tokom učenja i nastave L2.

Kada je riječ o metodologiji, oslanjaću se na naučnu disciplinu Teorija usvajanja L2 (SLA - Second Language Acquisition) koja se fokusira na formalna obilježja jezika. Da bih postigla zadate ciljeve, proučavaću kako se kod studenata, kroz vrijeme, razvija sposobnost da produkuju određene gramatičke strukture: upotreba pomoćnog glagola kod složenih vremena u glagolskoj sintagmi, lične zamjenice direktnog $i$ indirektnog objekta, upotreba priloga, elidovanje, inverzija subjekta u upitnim kaluzama, eufonično $-t$-, slaganje u rodu i broju u imeničkoj sintagmi, prijedlozi, kao i drugi oblici o kojima će biti više riječi u trećem dijelu.

Dokaz da su studenti savladali francusku gramatiku bio bi ukoliko bih na kraju posmatranog perioda konstatovala da se studenti služe pomenutim gramatičkim obilježjima jednako precizno kao izvorni govornici standardnog francuskog jezika.

Ova studija slučaja bavila se analizom jezičke produkcije grupe studenata prve godine studija francuskog jezika i književnosti u Nikšiću, u vremenskom periodu od septembra 2019. do juna 2020. Pored toga, da bih mogla da uporedim pomenuta formalna obilježja njihove jezičke produkcije $u$ početnoj fazi učenja sa produkcijom studenata koji su $u$ završnoj fazi učenja, prikupila sam jezičku produkciju studenata četvrte godine.

Sakupila sam usmene i pisane uzorke studentskih sastava na $L 2$ tokom određenog vremenskog perioda, u ovom slučaju tokom dva semestra od septembra 2019. do juna 2020. Transkribovala sam usmene uzorke čije je trajanje variralo od pet do deset minuta. Moj cilj bio je da opišem uočene greške, da ih objasnim, procijenim i ustanovim kako se

${ }^{1}$ Target language (ciljni jezik je svaki jezik koji se uči, L2, L3, etc.) vs. source language (izvorni jezik, pored maternjeg to može biti i svaki jezik koji može da utiče na učenje ciljnog jezika) (Vujović 18). 
one mijenjaju kroz vrijeme, po metodologiji SLA (Teorija usvajanja L2) (Elis 1997, 16-23).

Istraživački postupak ima tri etape:

1. Najprije ću tokom zimskog semestra ustanoviti koje greške studenti najčešće prave, nastaviću da pratim njihovu produkciju i tokom ljetnjeg semestra da bih ih na kraju uporedila. Tokom cijelog perioda realizovaću seriju ciljanih nastavnih aktivnosti što će mi omogućiti da na kraju posmatranog perioda ustanovim da li je došlo do promjene u upotrebi jezika, koje su greške izostale na kraju, a koje su još uvijek uočljive.

2. Istovremeno, sakupiću sastave studenata završne godine studija kako bih utvrdila koje greške karakterišu njihov međujezik.

3. Uporediću rezultate analize s kraja drugog i sa kraja osmog semestra kako bih došla do zaključaka o tome koje greške su prisutne i na kraju obrazovnog procesa i šta karakteriše međujezik strudenata francuskog jezika.

\section{Teorijska zasnovanost - Učenje odnosno usvajanje drugog jezika (L2)}

Naučna disciplina Teorija usvajanja L2 (Second Language Acquisition - SLA) ${ }^{2}$ (Elis 1997, 3) bavi se načinom na koji ljudi uče L2, jezik koji nije njihov maternji, u učionici ili izvan nje. SLA ima za cilj da opiše (description of L2) kako se odvija usvajanje odnosno učenje L2, da objasni (explanation) taj proces tako što bi utvrdila unutrašnje (internal) i spoljašnje (external) faktore koji utiču na to da studenti usvajaju L2 na

\footnotetext{
${ }^{2}$ Elis dalje ističe da se na prvi pogled, termin Second Language/drugi jezik čini transparentnim ali da on zahtijeva objašnjenje. Riječ second/drugi može da se odnosi na bilo koji jezik koji se uči nakon maternjeg jezika (L1). Isto tako, termin drugi jezik nije u opoziciji u odnosu na strani jezik. Bilo da se jezik uči spontano tokom boravka u zemlji gdje se on govori ili pak u učionici kroz nastavu, riječ je o učenju drugog jezika. M. N. Vujović (15) podsjeća da je maternji L1 jezik koji je hronološki prvi naučen ali i da pojedini lingvisti smatraju da se maternjim može smatrati onaj jezik koji je najdominantniji jezik, koji se najčešće koristi ili koji pojednac smatra svojim L1; s druge strane postoje neslaganja i u vezi sa definisanjem termina $L 2$, pa pojedini teoretičari smatraju: ' $L 2$ je jezik koji se uči u stranoj zemlji, među maternjim govornicima tog jezika (npr. slučaj emigranta). Razlikuje se od stranog jezika - nematernjeg jezika koji se uči u veštačkim uslovima, odnosno kroz formalno obrazovanje (Munoz 2002; Cortés 2005; Pallotti 2007).' Drugi pak smatraju da termin strani ima negativnu političku konotaciju; pored toga, prisutan je i stav da ovaj termin nije adekvatan u slučajevima kada govornici dostignu veoma visoku jezičku kompetenciju i ne doživljavaju ga kao strani.
} 
određeni, njima svojstven način, i da utvrdi zbog čega su neki studenti uspješniji od drugih.

Elis podsjeća (1994, 692) da S. Krašen (1981) pravi razliku između pojmova acquisitions (usvajanje) i learning (učenje). Prvi pojam odnosi se na spontani proces učenja jezika koji se odvija u prirodnom okruženju poput onog tokom kojeg djeca do desete godine usvajaju maternji ili neki drugi jezik, gdje je pažnja usmjerena prvenstveno na značenje a ne na formu, za razliku od learning (učenje) kojim se označava svjesni proces učenja (Vujović 18).

U ovom radu koristiću termin učenje budući da je riječ o svjesnom i željenom procesu koji se realizuje u institucionalnom okviru. Jedan od načina da se prouči kako se odvija učenje drugog jezika jeste da se prvo prikupe uzorci jezičke produkcije studenata kada se od njih traži da upotrijebe $L 2$ u govoru ili u pisanim sastavima - i da se pažljivo analiziraju. Takvi uzorci pružaju dokaz o tome šta studenti znaju o ciljnom jeziku (R. Elis, 1997: 4). Ovaj pristup oslanja se na Selinkerovu hipotezu o međujeziku (IL - interlanguage hypothesis) (Selinker et al. $1975,140)$ po kojoj relevantni podaci teorije učenja drugog jezika moraju biti oblici govora koji su rezultat pokušaja da se izrazi neki smisao na drugom jeziku. Kriterijum na koji se oslanja IL je da govornik pokušava da izrazi neki smisao na L2 za razliku od strukturalnih vežbanja na času čiji je cilj dril a ne izražavanje sopstvenog mišljenja.

Ukoliko se uzorci prikupljaju u različitim vremenskim periodima, moglo bi se utvrditi kako se njihovo znanje postepeno razvija i kako se njihov jezik mijenja kroz vrijeme.

Veoma važan aspekt učenja i usvajanja ciljnog jezika je jezički transfer. ${ }^{3}$ "Transfer je uticaj koji proizilazi iz sličnosti i razlika između ciljnog jezika i bilo kog drugog jezika koji je ranije (i možda i nesavršeno) naučen" (Odlin 27 kod Vujović 170). Dakle, osim maternjeg jezika (L1) i svi ostali jezici utiču na učenje ciljnog jezika.

\footnotetext{
${ }^{3}$ Ovaj termin prvi upotrebljavaju bihevioristi počev od pedesetih godina prošlog vijeka u okviru Kontrastivne analize (KA) koja zastupa stav da do pojave transfera dolazi kod nesrodnih jezika. Kasnije, sa kritikom KA, dolazi do novih saznanja o procesima učenja jezika pa U. Weinreich $(1953 ; 1968)$ koristi termin interference, language mixing (Selinker, Kellerman, Odlin), interlingual error (Dulay, Burt, Krashen), uvodi cross-linguistic interference, transfer analysis (James), De Angelis \& Selinker koriste termin interlanguage transfer, i dr. "Posle konferencije o jezičkom transferu u Mičigenu 1981. (The Michigan Conference of Language Transfer) u literaturu ulazi izraz koji su prvi put pomenuli Kellerman i Sharwood-Smith cross-linguistic interference. " (Vujović 173).
} 
Selinker (1992) razlikuje pozitivni, negativni i neutralni transfer, u zavisnosti od toga da li tokom prilagođavanja sintaksičkih i drugih struktura dolazi do nastanka grešaka u međujeziku. Pozitivni transfer karakterističan je za srodne jezike i olakšava učenje ciljnog jezika (Andersen 178) dok negativni transfer otežava učenje ciljnog jezika i on je prisutan između tipološki udaljenih jezika.

Negativni transfer ${ }^{4}$ se lako uočava jer često dolazi do stvaranja negramatičkih konstrukcija pod uticajem prethodnih zanja iz drugih jezika ili usled nemogućnosti da se asimiluju forme i strukture ciljnog jezika u već postojeći sistem (na primjer poteškoće kod usvajanja i učenja francuskih nazalnih fonema za studente čiji je maternji jezik $\mathrm{BCHS).}$

Pozitivni transfer predstavlja i strategiju koja pomaže učenicima da prevaziđu poteškoće u učenju ili upotrebi L2 na način što im znanje drugih jezika pomaže da nadomjeste praznine u poznavanju ciljnog jezika.

Neutralni transfer podrazumijeva da uglavnom nema uticaja. ${ }^{5}$ Novija istraživanja ukazuju na činjenicu da je neophodan uslov za nastanak transfera tipološka sličnost jezika L1 i L2 (Andersen, Transfer to Somewhere, 1983) ali Kellerman (Transfer to Nowhere, 1995) nalazi da je on prisutan i kod onih jezika koji to nijesu. Kellerman u svom radu ističe da, osim sintaksičkog restrukturiranja i prilagođavanja, učenje novog jezika podrazumijeva promjenu konceptualnog okvira kroz koji učenik doživljava svoje okruženje pa veću poteškoću u učenju predstavlja uočavanje konceptualnih razlika u ciljnom jeziku nego sličnosti i razlika u jezičkim strukturama (Vujović 174).

Do transfera dolazi na svim jezičkim podsistemima, pravopisnom, fonetskom, fonološkom, morfološkom, leksičkom, sintaksičkom, semantičkom, pragmatičkom i retoričkom (Corder 1981; Elis 1985; Odlin 1989; Larsen-Freman \& Long 1991; kod Vujović 173-174).

Kontrastivna analiza, analiza grešaka i međujezik - tri faze u razvoju analize grešaka u produkciji na $\mathbf{L 2}$

Pristup greškama razlikuje se kod različitih metoda koje se bave analizom procesa učenja drugog jezika. U okviru primijenjene lingvistike,

4 O tipovima negativnog transfera govori Odlin $(1989,27)$ a to su: underproduction; overproduction; production errors - substitution, calques, alternations of structures; misinterpretation; (kod kod Vujović 176-177).

${ }^{5}$ Nulti transfer (zero transfer) je termin koji koriste Stockwell i Bowen (1965) a podrazumijeva odsustvo transfera usled potpune različitosti jezičkih sistema. 
razvijaju se metoda kontrastivne analize (KA) kao i metoda analize grešaka $(A G)$ a jedna od suštinskih razlika među njima ogleda se u načinu na koji objašnjavaju greške.

KA metoda pojavljuje se pedesetih godina $X X$ vijeka. ${ }^{6}$ Ona se bavi poređenjem cjelovitih jezičkih sistema maternjeg i ciljnog jezika $\mathrm{i}$ ima za cilj da otkrije sličnosti i razlike u strukturama i upotrebi L1 i L2. Međujezičke razlike stvaraju najviše problema u učenju dok sličnosti između maternjeg i ciljnog jezika olakšavaju učenje.

KA pokušava da identifikuje $i$ da anticipira strukture koje bi mogle da predstavljaju poteškoće prilikom učenja ciljnog jezika kao i greške do kojih može doći tokom učenja.

Greška u kontrastivnoj analizi ima značenje odstupanja od norme i posmatra se kao negativna pojava koja nastaje pod uticajem interferencija iz maternjeg jezika a od nastavnika se očekuje da odmah ispravi grešku.

Sedamdesetih godina dvadesetog vijeka pojavljuje se AG metoda (Analiza grešaka) zahvaljujući S. P. Korderu (Corder 1967) koji izučava greške koje nastaju u usmenoj i pisanoj jezičkoj produkciji učenika. Ova metoda ima za cilj da opiše i analizira uzroke njihovog nastanka, kao i strategije kojima učenici pribjegavaju tokom procesa učenja.

Analiza uzoraka jezičke produkcije realizuje se u nekoliko etapa koje podrazumijevaju: identifikaciju grešaka, njihov opis, klasifikaciju i evaluaciju. AG se bavi pitanjima međujezičke interferencije.

Greška postaje izvor informacija i pokazatelj trenutne jezičke kompetencije ali i osnova za unapređivanje nastave koje ima za cilj bolje napredovanje u učenju. Ona se više ne posmatra kao odstupanje od norme već je to dokaz da je proces učenja u toku i greška predstavlja neohodnu etapu u učenju sistema ciljnog jezika (Richards 173); greška je posledica napretka učenika a ne dokaz neuspjeha i predstavlja rezultat primjene strategije učenja (Corder 1967) (Vujović 93-94). Od nastavnika se ne očekuje da ispravlja greške već se učenici upućuju na samokorekciju.

AG uvodi razliku između termina mastake (omaška) i error (greška).

Korder $(1967,167)$ razlikuje grešku (systemic error) od omaške (nonsystemic error). Greške ukazuju na propuste i nedostatke u poznavanju ciljnog jezika. One nastaju zbog toga što učenik ne zna kako glasi pravilna struktura. To su greške kompetencije koje daju važne podatke o procesu

${ }^{6}$ Lado, R. (1957) Linguistics across Cultures. Ann Arbor: University of Michigan Press. 
učenja jer mogu da ukažu na to šta učenik trenutno zna (tranizitorna kompetencija) i kako se mijenja njegovo znanje kroz vrijeme odnosno kako napreduje učenje ciljnog jezika.

Omaške ukazuju na povremene lapsuse do kojih dolazi usljed spoljašnjih uticaja, pada koncentracije ili emotivne reakcije kada učenik nije u stanju da pokaže ono što zna.

Pa ipak, uočeno je da AG ne može da utvrdi precizne kriterijume za kategorizaciju grešaka (Dulay et al. 141-146) ali ni da objasni njihov uzrok pa se dalja istraživanja u ovoj oblasti okreću konceptu međujezika.

\section{Međujezik}

Međujezik je centralna tema u istraživanjima Teorije učenja L2 (SLA) koju razvija američki lingvista Lari Selinker (Larry Selinker). Pojmom međujezik (Interlanguage) prepoznaje se činjenica da učenici konstruišu lingvistički sistem koji djelimično proizilazi i naslanja se na učenikov maternji jezik L1 (LM) ali je ipak različit od njega, kao i od ciljnog jezika L2 (LC) (Elis 1997, 33).

Selinker (1972) uočava da se u nekoj određenoj situaciji iskazi koje učenik koristi razlikuju od iskaza koje bi izvorni govornici upotrijebili ako bi htjeli da izraze isto značenje. ${ }^{7}$ Selinker govori o latentnim psihološkim strukturama u svijesti (one se vezuju za genetsku određenost i urođenu sposobnost učenja jezika) koje se aktiviraju kada učenik pokušava da nauči L2. U ovim strukturama Selinker $(1972,215)$ razlikuje pet kognitivnih procesa koji se odvijaju onda kada učenici pokušavaju da nauče L2.

Sledeći procesi utiču na formiranje jezičkog sistema koji se razlikuje i od maternjeg jezika L1 i od ciljnog jezika L2: 1. jezički transfer, 2. transfer podučavanja, 3. strategije učenja L2, 4. strategije komunikacije na stranom jeziku, 5. prekomjerna generalizacija lingvističkog materijala stranog jezika.

Jezik kojim govore studenti nije samo rezultat razlika između jezika koje već znaju i jezika koji upravo uče, već je riječ o cjelovitom i potpunom jezičkom sistemu, koji ima sopstvena pravila. Strukture koje nastaju u okviru međujezika nijesu proizvoljne.

R. Elis u trećem poglavlju SLA $(1997,33)$ ukazuje na premise na kojima se zasniva učenje L2:

1. Učenik kreira sistem apstraktnih jezičkih pravila (mentalnu gramatiku) koja omogućavaju razumijevanje i izražavanje (produkciju) na L2 - intelanguage.

${ }^{7}$ (https://en.wikipedia.org/wiki/Interlanguage. 29. jul 2020. 
2. Učenikova gramatika je propusna odnosno otvorena za spoljašnje uticaje (putem inputa/objašnjenja) ali i za unutrašnje uticaje. Dokaz tih unutrašnjih procesa su pretjerana upotreba nekih struktura, izostavljanje i transferne greške koje nastaju usled preuzimanja struktura iz L1.

3. Učenička gramatika je tranziciona. Učenici restrukturiraju cjelokupni sistem sopstvene upotrebe L2 što ukazuje na postojanje međujezičkog kontinuuma (interlanguage continuum).

4. Međujezik se sastoji od varijabilnih pravila dok drugi smatraju da je međujezik homogen a varijabilnost dolazi do izražaja u omaškama koje učenici prave tokom procesa učenja jezika L2 i pokušaja ostvarivanja komunikacije.

5. Učenici razvijaju raznovrsne strategije učenja kako bi razvili svoj međujezik. Tip grešaka koje prave odražava zapravo njihovu strategiju učenja.

6. Fosilizacija je odlika međujezika (rana razvojna faza - backsliding). Selinker smatra da samo $5 \%$ učenika uspije da razvije potpuno istu mentalnu gramatiku kao izvorni govornici. Većina se zaustavi na nekoj od ranijih faza.

\section{Analiza grešaka u jezičkoj produkciji: opis i klasifikacija grešaka}

Međujezik zapravo predstavlja fazu u procesu učenja L2 koja pomaže učenicima da mentalno restrukturiraju nova znanja odnosno oblike, strukture i funkcije koje uče.

Da bismo proučili međujezik (interlanguage) studenata potrebno je da analiziramo njihovu jezičku produkciju metodom analize grešaka.

Procedura opisa grešaka podrazumijeva dvije faze:

a) Potrebno je najprije uočiti greške. Da bismo mogli da identifikujemo greške, potrebno je da uporedimo rečenice sa onima koje se smatraju pravilnom upotrebom jezika.

b) Zatim treba opisati greške i razvrstati ih po tipu.

Klasifikovanje grešaka može da pomogne pri dijagnostikovanju učenikovog znanja u svim fazama učenja ali i da ilustruje kako se odvijaju promjene u kompetencijama kroz vrijeme. Različi su načini klasifikacije grešaka.

Tornberi (Thornbury 75-76, kod Vujović 106-107) predlaže klasifikaciju koja se zasniva na sledećim kriterijumima:

- Jezički nivo odnosno podsistem na koji se greške odnose (greške u izgovoru, u vokabularu, u gramatici, u dikursu).

- Način na koji odstupaju od norme (greške u izostavljanju - omission, u dodavanju - addition, u pogrešnom odabiru - mis-selection, 
greške u prenošenju pogrešne informacije - mis-information, u redosledu riječi - misordering).

- Uzrok zbog kojeg nastaju (greške izazvane transferom - transfer errors, razvojne greške - developmental errors).

- Stepen ozbiljnosti (globalne - global errors, lokalne greške - local errors). ${ }^{8}$

Elis (1997) navodi da je moguće klasifikovati ih prema gramatičkim kategorijama (na primjer, sve greške koje se odnose na glagole, nakon toga, utvrditi o kakvim je greškama riječ); treba razumjeti na koji način se učenikova produkcija na ciljnom jeziku razlikuje od norme. Tu može doći do:

- izostavljanja (omission);

- pogrešne upotreba gramatičkog oblika (misinformation) što znači, upotreba jednog umjesto drugog oblika koji predstavlja pravilnu upotrebu;

- pogrešnog redosleda riječi u rečenici (misordering).

c) Nakon toga treba objasniti greške.

Greške su često sistemske (primjer upotrebe prostih umjesto složenih vremena ukazuje na to da je učenik stvorio neku vrstu pravila - rule koje se razlikuje od ciljnog jezika).

Međutim, greške mogu biti i univerzalne što znači da se pojavljuju kod velikog broja učenika, o čemu će biti riječi u dijelu koji slijedi.

Nekada se određeni tip grešaka uočava kod govornika koji imaju zajednički maternji jezik ili njihovi maternji jezici imaju zajedničke lingvističke karakteristike. Ovdje je riječ o transfernim greškama (transfer errors) koje nastaju zato što govornici imaju tendenciju da na L2 primjenjuju pravila iz L1. Dakle, greške imaju različito porijeklo.

Univerzalne greške odražavaju težnju da se učenje stranog jezika pojednostavi.

Tu se javlja greška izostavljanja (omission). Uočena je i pretjerana upotreba (ovregeneralization) nekih oblika koje učenici smatraju jednostavnijim za učenje (Elis navodi primjer: eated umjesto ate).

Izostavljanje i pretjerana upotreba javljaju se kod svih polaznika koji uče L2 bez obzira na njihov maternji jezik.

d) Na kraju, potrebno je procijeniti greške (Elis 1997, 19-20) naročito kada je cilj analize grešaka da se pomogne učenicima da uče L2.

R. Elis predlaže podjelu na globalne i na lokalne greške. Globalne greške ruše ukupnu strukturu rečenice i mogu da otežaju proces učenja.

${ }^{8}$ M. N. Vujović (96) poziva se na podjelu koju su predložili Burt \& Kipersky, 1972; Dulay et al. 1982. 
Lokalne greške utiču na samo jedan sastavni deo rečenice (na primjer, na glagolsku sintagmu) i manje je verovatno da će stvoriti bilo kakav problem u obradi odnosno, uprkos greškama, razumijevanje usmene i pisane produkcije nije onemogućeno.

U dijelu koji slijedi, izložiću karakteristike jezičke produkcije studenata francuskog jezika čiji je maternji jezik BCHS.

\section{Analiza grešaka u jezičkoj produkciji studenata prve godine studija francuskog jezika \\ U ovom dijelu rada, posmatraćemo formalna obilježja jezičke produkcije studenata prve godine. Slijede opisi, kategorizacija, objašnjenje i procjena grešaka prikupljenih u okviru ove studije slučaja koja se odnosi na period od dva semestra i to na: početak posmatranog perioda u cilju dijagnostikovanja, na kraj prvog semestra radi praćenja napredovanja, i na kraj ljetnjeg semestra kada ćemo dobiti uporedive podatke o postignućima.}

\section{Uočene greške na početku posmatranog perioda i opis grešaka - usmeno razumijevanje}

Prilikom prvih susreta sa studentima, u cilju dijagnostikovanja njihovog znanja iz francuskog jezika, analizirala sam njihovu sposobnost da razumiju usmeno izlaganje. Da bih saznala koliko precizno studenti razumiju poruke, koncepte i ideje, da li, i u kojoj mjeri, prepoznaju gramatičke strukture kojima se isti materijalizuju u usmenom odnosno pisanom jezičkom registru, odlučila sam da najprije posmatram i analiziram način na koji studenti bilježe ono što su čuli.

Dakle, u ovoj fazi, na početku prvog semestra, na planu grafije uočila sam i popisala određene greške (primjeri su navedeni u Tabeli 1. koja je data u u Aneksu). Nakon ove faze, sa studentima sam posebno obrađivala navedene strukture ${ }^{9}$ da bih na kraju perioda od 15 sedmica ponovo analizirala grafiju, uporedila greške i pratila napredovanje. Dakle, uočila sam određene promjene u odnosu na početak učenja a greške sam razvrstala po osnovu gramatičkih kategorija. Cilj ovih aktivnosti bio je da utvrdim elemente koji karakterišu francuski jezik kojim govore studenti, njihov međujezik, i da opišem kako se on razlikuje od norme.

Ranije smo naveli da greške mogu biti sistemske, transferne i univerzalne. Dakle, sve tri vrste grešaka prisutne su u posmatranoj jezičkoj produkciji studenata prve godine.

\footnotetext{
${ }^{9}$ Kod Elisa Imput based acquisition (1997, 88-89).
} 
Sistemske greške ukazuju na to da je došlo do formiranja određenih pravila u jeziku studenata i da se ista razlikuju od pravila u francuskom jeziku. Ove greške ukazuju na stvaranje međujezika. Transferne greške vezuju se za uticaj znanja iz maternjeg jezika LM (L1). Univerzalne greške odnose se na izostavljanje (omission) i pretjeranu upotrebu (overgenralization) što ukazuje na tendenciju studenata da pojednostavljuju jezik kojim govore odnosno na strategije kojima se služe tokom učenja L2.

Slijedi opis uočenih grešaka na početku zimskog semestra.

Sistemske greške:

- izostavljanje pomoćnog glagola avoir *je manquais/-é umjesto j'ai manqué,

- pogrešna upotreba glagola être *cet umjesto c'est, * ${ }^{*}$ 'est umjesto c'était,

- pogrešno slaganje participa perfekta što podrazumijeva složena znanja *guéri umjesto guérie,

- tendencija upotrebe indikativa umjesto subjuntiva *que tu es umjesto que tu aies,

- pogrešna upotreba predloga,

- izostavljanje foneme /z/ koja nastaje u procesu vezivanja suglasnika i vokala.

Transferne greške:

- izostavljanje elidovanja *que elle/que il/que on umjesto qu'elle/'il/'on. Moguće je da je riječ o uticaju znanja iz LM maternjeg jezika budući da u crnogorskom odnosno BSH jeziku fonetska riječ odgovara pisanoj [da oni] vs. [da ona],

- pogrešna fonetska diskriminacija vokala po osnovu kriterijuma: mjestu tvorbe, obliku i položaju usana, položaju jezika, položaju mekog nepca.

Univerzalne greške:

- izostavljanje nastavaka za lica u prezentu *tu mène, *qu'il soit, *produira-tu?,

- pogrešna upotreba imperativa u drugom licu jednine i drugom licu množine,

- pogrešna upotreba determinanata ce vs. ces, cet vs. c'est,

- slaganje u rodu i broju u okviru GN,

_ izostavljanje zamjenica en, $y^{*} q u^{\prime}$ elle...soit vs. qu'elle y soit, *il y ... a vs. il y en $a$,

- pretjerana upotreba i izostavljanje eufoničnog -t kod inverzije subjekta u upitnim klauzama *reçoit-t-il vs. reçoit-il. Problem je još 
veći u glagolskoj sintagmi koju odlikuje veliki broj vokala, kao na primjer: il essaie čija je fonetska struktura V-C-V [i-le-se] *essaient$t$-ils vs. essaient-ils, *que a on dit vs. qu'a-t-on dit,

- izostavljanje udvojenog suglasnika u grafiji participa fallu, *falu, ili kod glagolske osnove*alons vs. allons,

- greške u upotrebi dijakritičkih znakova *apercu vs. aprerçu, *melancolique vs. mélancolique, *depart vs. départ.

\section{Opis grešaka na kraju zimskog semestra}

Kao jedna od najprisutnijih sistemskih grešaka uočena je pogrešna upotreba pomoćnih glagola koja je prisutna i na početku i na kraju prvog semestra. Ovdje je riječ o složenim znanjima pa je i za očekivati da se takva znanja postupno usvajaju. Pa ipak, dok se pomoćni glagol avoir sistematski izostavlja na početku ovog perioda, na kraju semestra prisutne su omaške jer je u nekoliko slučajeva pomoćni glagol izostavljen dok je u ostalim primjerima pravilno upotrijebljen.

Uočena je progresija i u upotrebi elidovanja. Ove promjene ukazuju na progresiju u međujeziku potvrđujući njegovu kontinuiranost i tranzitornost kompetencija. Još jedna pojava mogla bi biti potvrda da je došlo do formiranja određenih pravila u međujeziku, ona se odnosi na tendenciju da se particip perfekta nepravilnih glagola formira po ugledu na oblike participa perfekta pravilnih glagola. Pored toga, prisutna je i sistematska pogrešna upotreba predloga.

$\mathrm{U}$ transferne greške mogle bi se uvrstiti greške do kojih dolazi prilikom elidovanja. Studenti teško usvajaju pravilo da dvije riječi koje su spojene u grafiji pomoću apostrofa čine jednu fonetsku cjelina odnosno fonetsku riječ.

Osim toga, prisutne su i poteškoće prilikom povezivanja fonema sa odgovarajućim grafemama što se može objasniti znanjima koja studenti imaju o maternjem jeziku u kojem jedna grafema odgovara jednoj fonemi. Ovdje je očigledno riječ o negativnom transferu iz maternjeg jezika koji otežava asimilaciju novih znanja o fonetskom sistemu francuskog jezika.

Isto tako, uočeno je da studenti prave pravopisne greške kada pokušavaju da pribilježe fonetske riječi. Uzrok bi moglo biti nedovoljno poznavanje osnovnih jezičkih struktura i fonetskog sistema ciljnog jezika. Ovakve greške svojstvene su većini studenata i možemo ih ubrojiti u univerzalne greške. Pored toga, istoj kategoriji grešaka pripada i pogrešno slaganje u rodu i broju u imeničkoj i u glagolskoj sintagmi. Najčešće je riječ o izostavljanju nastavaka za lice, za rod i broj. Slične greške prisutne su na početku i na kraju ovog posmatranog perioda. 
Sistemske greške i omaške:

- omaške u upotrebi pomoćnog glagola avoir koji je u nekoliko slučajeva izostavljen ali je u ostalim slučajevima pravilno upotrijebljen,

- particip perfekta kod nepravilnih glagola pogrešno se formira po ugledu na oblike pravilnih glagola,

- demonstrativ se koristi umjesto povratne zamjenice *ce qui ce passe vs. ce qui se passe,

- pogrešna upotreba glagola kopule être * ces vs. c'est. Uočene su poteškoće kod diskriminacije zatvorene [e] i otvorene $[\varepsilon]$ varijante foneme /E/,

- infinitiv iz modalnih struktura zamjenjuje se formom participa perfekta *je n'aime pas dancé vs. je n'aime pas danser,

- pogrešna upotreba relativne zamjenice gdje se qui eliduje ispred $i l \mathrm{i}$ formalno supstituira veznikom que odnosno qu' *un type $q u^{\prime} i l m^{\prime} a$ proposé vs. un type qui m'a proposé,

- omaške u upotrebi priloga i prijedloga, usljed poteškoća prilikom diskriminacije francuskih vokala po osnovu kriterijuma: mjestu tvorbe, obliku i položaju usana, položaju jezika *à ce moment vs. en ce moment.

Transferne greške:

- omaške prilikom elidovanja *je n'sais pas vs. je ne sais pas. Sada je riječ o pretjeranoj upotrebi što ukazuje na progresiju u međujeziku,

- kod negacije dolazi do izostavljanja drugog dijela pas (ne $+V E R B E+$ pas) što ukazuje na transfer iz LM gdje se koristi samo riječ $n e+V$,

- sa neodređenom ličnom zamjenicom on pogrešno se upotrebljava glagol u trećem licu množine, ovdje dolazi do direktnog transfera iz LM preko asocijacije (Elis, 1997: 87) na formu lične zamjenice subjekta on ili oni u BCHS na šta se nadovezuje znanje o tome da ova zamjenica u francuskom jeziku može da se odnosi na više nepoznatih lica pa otuda i nastavak trećeg lica množine u produkciji studenata *on ne sont pas vu vs. on ne s'est pas vu,

- u složenim strukturama postoji odsustvo primjene pravila slaganja vremena što asocira na upotrebu vremena u BCHS jezicima gdje ne postoji isto pravilo *je croyais que tu n'aime pas danser vs. [...] que tu n'aimais pas danser,

Univerzalne greške:

- izostavljanje ili pogrešna upotreba nastavaka za lica u prezentu *je m'en sent vs. je me sens, 
- pogrešna upotreba determinanata (demonstrativ vs. povratna zamjenica, demonstrativ vs. pomoćni glagol, neodređeni član vs. prijedlog),

- slaganje u rodu i broju u okviru GN * ce nuit,

- nepravilna upotreba ekcenata, izostavljanje ili pretjerana upotreba *j'ai rencontre vs. j'ai rencontré, * l'éxistence vs. l'existence,

- pogrešna fonetska diskriminacija vokala po osnovu kriterijuma: mjesta tvorbe, oblika i položaja usana, položaja jezika, položaja i uloge mekog nepca, otvoreno $[\varepsilon]$ vs. nazalno $[\tilde{\varepsilon}]-u$ riječi copain, nijemo [ə] vs. otvoreno $[\varepsilon]-$ u sintagmi $^{*}$ Ce vs. C'est.

\section{Greške na kraju ljetnjeg (drugog) semestra u usmenoj jezičkoj produkciji studenata, opis grešaka \\ $U$ drugoj fazi ovog istraživanja analizirala sam usmenu produkciju} studenata tokom ljetnjeg semestra sa ciljem da uporedim uočene greške sa onim što se smatra pravilnom upotrebom tih struktura u standardnom francuskom jeziku.

a. Greške su bilježene tokom usmene produkcije studenata kojoj je prethodila pismena priprema. Studenti su dobili uputstvo: ispričajte jedan događaj koji vas je naročito dirnuo i ostavio utisak na vas. Pismeni sastavi nastali tokom pripreme za usmeno izlaganje korišćeni su za analizu grešaka i upotpunjeni su bilješkama koje je profesor vodio tokom usmene prezentacije.

b. Osim toga, opisane su greške i u usmenoj produkciji studenata na poznate teme, bez prethodne pismene pripreme. Studenti su dobili zadatak i uputstvo da ispričaju jednu epizodu iz romana Le Petit Prince na kojem su radili, samostalno ili na časovima, u prethodnom periodu. Tokom pomenute aktivnosti, zabilježila sam usmenu jezičku produkciju studenata da bih je nakon toga transkribovala.

Greške sam razvrstala po osnovu gramatičkih kategorija a zatim sam izdvojila elemente koji karakterišu njihov međujezik što je objašnjeno u dijelu koji slijedi (primjeri su navedeni u Tabeli 2. koja je data u Aneksu).

\section{Objašnjenje grešaka}

Na kraju prve godine studija, uočila sam sve tri vrste grešaka u jezičkoj produkciji studenata: sistemske, transferne (LM) i univerzalne. Navešćemo ih u tekstu koji slijedi. 
Sistemske greške koje ukazuju na činjenicu da je došlo do formiranja određenih pravila u govoru kojim se služe studenti a koja se razlikuju od pravila u francuskom standardnom jeziku, su sledeće:

- pogrešna upotreba pomoćnog glagola kod intranzitivnih i pronominalnih glagola tako da se koristi glagol Avoir umjesto glagola Être. Ovdje je zabilježena nedovoljna diskriminacija intranzitivnih $\mathrm{i}$ povratnih glagola s jedne strane, i tranzitivnih glagola, sa druge:

*il a tombé umjesto il est tombé (kao i kod glagola devenir, partir, tomber, etc.),

*il a posé umjesto il s'est posé (v.pr. se poser sur),

* nous nous avons effrayé umjesto nous nous sommes effrayés (v.pr. s'effrayer);

- pogrešna upotreba pronominala (*il a posé sur umjesto il s'est posé),

- usled gorenavedene pogrešne upotrebe pomoćnog glagola, dolazi do pogrešne upotrebe participa perfekta kao i odsustva slaganja u rodu i broju sa subjektom;

- pogrešna upotreba predloga (*ressembler de);

- pogrešna upotreba mjesto zamjenice indirektnog objekta $\left({ }^{*} i l\right.$ a dit à lui umjesto il lui a dit);

- složene strukture sa indirektnim govorom i izjavnom rečenicom (v. tr. *dire + si umjesto v. tr. dire + que predlog).

Transferne greške odnose se na:

- elidovanja koje se najčešće izostavlja (que elle umjesto qu'elle) ali se ponekad, dosta rijetko, i pretjerano koristi *que elle est vs. qu'elle est, *s'on vs. si (l')on);

- upotrebu glagola devoir gdje studenti imaju tendenciju da koriste oblik 3 lica jednine i kada je potrebno iskazati treće lice množine (il doit vs. ils doivent) po ugledu na naš glagol trebati koji se u BHCS koristi u 3 licu jednine Studenti treba da predaju seminarske radove;

- upotrebu predloga de (chercher de lui umjesto lui demander) što podsjeća na konstrukciju tražiti, zahtijevati od nekoga da;

- upotrebu predloga à, *il répéta à longtemps umjesto il répéta longtemps, što podsjeća na riječ nadugo koja je nastala spajanje prefiksa na i priloga dugo.

U univerzalne greške $\mathrm{i}$ omaške spadaju izostavljanje i pretjerana upotreba čime studenti zapravo pojednostavljuju jezik kojim se služe, a to se dešava kod:

- pretjerana upotreba nastavaka $-t$ u i licima imperfekta: * $j^{\prime}$ était umjesto j'étais; 
- omaške prilikom izostavljanja oznake za broj u nekom od konstituenata imeničke sintagme (GN) *deux autre magasins umjesto deux autres magasins;

- pretjerana upotreba bilo člana muškog ili člana ženskog roda kod imenica;

- izostavljanja predloga (quand tu tiens quelque chose umjesto quand tu tiens à quelque chose) ili pretjerana upotreba (dit à lui que umjesto lui dit);

- izostavljanja lične zamjenice direktnog objekta (sa rose, *il a apprivoisé umjesto sa rose, il l'a apprivoisée);

- upotreba složenih jezičkih struktura poput indirektnog pitanja gdje se pretjerano i neopravdano uvodi inverzija subjekta *ils te demandent combien pèses-tu vs. ils te demandent combien tu pèses;

- slaganje participa perfekta u rodu i broju sa subjektom kada je riječ o glagolima stanja ili o pasivu, gdje dolazi do omaške a ne do greške što je očigledno u narednom primjeru gdje je prisutno slaganje $u$ rodu ali nije u broju budući da je izostavljen znak -s za množinu: *nous étions très fatiguée umjesto nous étions très fatiguées.

Kada je riječ o progresiji u međujeziku na kraju ljetnjeg semestra uočila sam sljedeće pokazatelje:

- Progresija na planu sistemskih grešaka:

Na kraju posmatranog perioda nijesu zabilježene greške prilikom upotrebe glagola avoir kao što je to bio slučaj u prethodnom periodu.

Greške prilikom upotrebe glagola être sada se vezuju za složena znanja kod upotrebe perfekta (le passé composé) a ne više kod pogrešne upotrebe i nerazlikovanja ovog glagola od demonstrativa (problem na nivou fonetske diskriminacije varijanti foneme $\mathrm{E}$ ).

Kod participa perfekta (PP), sada imamo greške koje se vezuju za usvajanje složenih znanja i slaganje PP u rodu i broju sa subjektom odnosno direktnim objektom dok je ranije bila riječ o problemu na planu morfologije i tendencije da se svi oblici PP formiraju po ugledu na PP glagola prve grupe.

- Progresija na planu transfernih grešaka:

Elidovanje, od potpunog izostavljanja do pretjerane upotrebe. Odsustvo grešaka u upotrebi negacije koje su ranije bile prisutne. Slično i sa upotrebom neodređene zamjenice $O N$.

- Progresija na planu univerzalnih grešaka:

Greške prilikom slaganja u rodu i broju u okviru GN, od grešaka vezanih za nepoznavanje roda imenice do povremenih omaški i izostavljanja oznake za množinu jednog od konstituenata GN. 
Upotreba determinanata takođe bilježi progresiju, sada imamo greške kod oznake za rod dok je ranije uočeno odstutsvo prepoznavanja pojedinih oblika i njihova pogrešna upotreba.

Kada je riječ o upotrebi nastavaka kod glagolskih vremena, u ranijem periodu greške su se odnosile na nastavke prezenta dok se sada greške uočavaju kod nastavaka imperfekta.

Kako učenje napreduje, o progresiji svjedoče i nove greške koje prvi put srijećemo poput pogrešne upotrebe glagolske dopune, pogrešne upotrebe predloga, slaganja vremena, sintaksa rečenice.

\section{Procjena grešaka}

Prilikom procjene grešaka, uočene su globalne greške koje ruše ukupnu strukturu rečenice i time otežavaju proces komunikacije i samog učenja ali i lokalne greške koje imaju manji negativni uticaj na strukturu diskursa.

Globalne greške:

- Sistematska pogrešna upotreba pomoćnog glagola može se smatrati globalnom greškom jer u navedenim primjerima dovodi do potpune ili djelimične promjene u značenju.

- Isto tako, upotreba neadekvatnih veznika kojima se povezuje glavna sa zavisnim rečenicama takođe dovodi do sematičkih promjena i do poremećaja u strukturi i u značenju.

- U greške koje razbijaju fluidnost govora spada sistematsko izostavljanje ili pogrešno elidovanje ali ono ne mora da utiče na razumijevanje same poruke.

- Pretjerana i neprecizna upotreba determinanta (člana u muškom ili u ženskom rodu) takođe veoma utiče na fluidnost i može djelimično da poremeti strukturu diskursa i njegovo razumijevanje.

- Neadekvatna upotreba indirektnog govora može se uvrstiti u globalne greške jer upotreba inverzije subjekta, karakteristična za direktni govor, može da dovede sagovornika u zabludu i da izazove efekat dvosmislenosti.

Lokalne greške

- Uočene transferne međujezičke greške ne utiču značajno na razumijevanje poruke $i$ to su one koje se odnose na izbor leksike, izostavljanje vezivanja usljed izostavljana oznake za broj u okviru imeničke sintagme (GN), zatim izostavljanje, pretjeranu ili pogrešnu upotrebu predloga.

- Pogrešna upotreba lične zamjenice direktnog odnosno indirektnog objekta (COD i COI) u navedenim primjerima mogla bi se uvrstiti u ovaj tip grešaka budući da se na osnovu konteksta ostvaruje razumijevanje strukture dok se problemi više uočavaju na planu fluidnosti i preciznosti. Ipak, ova vrsta greške mogla bi u drugim 
slučajevima da značajno poremeti diskurs i da proizvede efekat dvosmislnosti.

- Slaganje participa može da se uvrsti u lokalne greške kada na planu govora nema opozicije između oznake muškog i ženskog roda ili množine kao što je bio slučaj sa navedenim primjerima. U suprotnom, moglo bi da razbije rečeničnu strukturu.

\section{Greške u produkciji studenata četvrte godine studija francuskog jezika i književnosti}

Materijal koji su produkovali studenti četvrte godine studija odnosi se na više obrađivanih tema. Ova grupa studenata imala je period pripreme i usmeno izlaganje. Podatke za ovo istraživanje crpila sam iz pisanih sastava i iz transkripcije usmenih izlaganja. Kao i u prethodnim fazama istraživanja, razvrstala sam greške po osnovu gramatičkih kategorija i izdvojila elemente koji karakterišu jezik kojim govore studenti četvrte godine studija a po kojima se on razlikuje od norme (primjeri su navedeni u Tabeli 3. koja je data u u Aneksu).

\section{Objašnjenje i procjena grešaka}

Uočila sam sistemske greške u posmatranoj jezičkoj produkciji. To su one greške koje ukazuju na prisustvo procesa formiranja određenih pravila u govoru koja se razlikuju od pravila u francuskom standardnom jeziku i u njih se mogu ubrojiti:

- pogrešna upotreba pomoćnog glagola pa se koristi glagol Être umjesto glagola Avoir: * ils sont présenté les similitudes et les différences de [...] umjesto ils ont présenté les similitudes et les différences de [...]. Smatram da je ovdje riječ o omašci a ne o grešci na šta ukazuje nepromijenjeni particip perfekta, kao i to što je ova omaška rijetko prisutna u jezičkoj produkciji pomenute grupe studenata;

- pogrešna sintaksa impersonalnih struktura *il est important qu'on rend;

- odsustvo sažimanja sa određenim članom iza predloga *jusqu'à le moment umjesto jusqu'au moment moglo bi se posmatrati kao sistemska greška budući da je ovdje riječ o veoma udaljenim procesima i strukturama u odnosu na BHCS;

- odsustvo elidovanja ispred riječi koja počinje vokalom *du type de ustensile ukazuje na to da se formiralo određeno pravilo;

- stvaranje sopstvenih pravila u jeziku studenata, koja se razlikuju od upotrebe izvornih govornika, ogleda se u pogrešnoj upotrebi predloga: en vs. de; à vs. de; en vs. pendant; aux vs. dans; dans vs. de; 
- pogrešna upotreba složenih relativnih zamjenica umjesto kojih se koriste proste relativne zamjenice que, $q u^{\prime}$, dont, ukazuje na to da su studenti kreirali određena pravila u svojoj upotrebi jezika koja se značajno razlikuju od norme;

- greške prilikom povezivanja djelova složene klauze, pojednostavljivanje koje se ogleda u izostavljanju veznika ili relativnih zamjenica (*dans le style que nous aimons et ${ }^{*}$ ne nous est pas imposé, *la question est *les Français passent[...]);

- povremena neprecizna upotreba oblika subjunktiva na način da se izostavlja nastavak za glagolski način i lice -e: *il est important qu'on rend umjesto il est important qu'on rende što ukazuje na to da je riječ o omašci ili o grešci koja se više odnosi na sintaksu impersonalnih struktura.

Transferne greške odnose se na one koje se vezuju za znanja iz maternjeg jezika (LM), a uočene su sledeće:

- kod impersonalnih glagola (sa impersonalnom zamjenicom u 3 licu jednine $i l)$ studenti koriste nastavak 3 lica množine kao u primjeru koji slijedi: il existent des règles de la conversation umjesto il existe des règles de la conversation, po ugledu na rečenicu postoje pravila u BHCS jezicima;

- pretjerana upotreba povratne zamjenice vezuje za upotrebu ili znanja iz LM kao u primjerima ces choses peuvent *se changer umjesto peuvent changer što ukazuje na strukturu u našem jeziku ovakve stvari mogu da se promijene ili cela permet à la famille de *se socialiser da se druže;

- isto tako, kod izostavljanja povratne zamjenice uočavamo transferne greške: en lisant les livres et en *reposant umjesto en se reposant što ukazuje na transfer iz našeg jezika odmarajući;

- glagol aider quelqu'un je direktno tranzitivan ali po ugledu na naš glagol pomoći nekome često se pogrešno upotrebljava i u francuskom jeziku sa indirektnim objektom *aider aux gens;

- u strukturi regarder la montre, po ugledu na BHCS gledati na sat uočava se transferna greška *regarder sur la montre;

- kod upotrebe * se rapprocher avec kao u strukturi zbližiti se sa, umjesto se rapprocher de;

- pogrešan redosled priloga potiče iz povezivanja sa znanjima iz LM gdje se često koristi prije glagola dok on u francuskom jeziku slijedi nakon glagola *les gens souvent vont vs. les gens vont souvent;

- $\quad$ kod negativne forme rečenice izostavlja se drugi dio negacije pas što se može povezati sa negacijom u BHCS (...to ne daje... - ...cela ne 
donne pas...). Budući da se ovakva pogrešna upotreba rijetko srijeće u produkciji, riječ je vjerovatno samo o omašci a ne o grešci,

- nepravilno elidovanje je rijetko na ovom nivou pa je najvjerovatnije riječ o omaškama.

U univerzalne greške spadaju izostavljanje i pretjerana upotreba što ukazuje na primjenu strategija u učenju. Ovdje je riječ o pojednostavljivanju francuskog jezika kojim studenti govore a to je uočljivo u sledećim primjerima:

- izostavljanje oznake za lice * Les gens se rapproche avec la famille et [...], moglo bi se smatrati za omašku a ne za grešku jer studenti uglavnom pravilno koriste oblike prezenta i nastavke za lica;

- nakon negacije ne pas pretjerano se koristi predlog de *je n'ai pas de temps, umjesto ... pas le..., ili sažeti član des *il n'y a pas des... umjesto ... pas de...;

- neopravdano izostavljanje predloga de, profiter *l'occasion;

- pretjerana upotreba određenog člana u fiksiranim izrazima gdje on po pravilu nije prisutan réunis à table, * réunis à la table;

- omaške prilikom izostavljanja oznake za broj u nekom od konstituenata imeničke sintagme (GN) leurs vêtements, toutes les obligations - *à travers leur vêtement, * tous les obligations;

- pretjerana upotreba bilo člana muškog ili člana ženskog roda kod imenica un moyen, une manière - *une moyen, *un manière.

\section{Procjena grešaka}

Uvidom u primjere, zaključila sam da globalnim greškama pripadaju one koje se odnose na:

- izostavljanje veznika u okviru složenih rečeničnih struktura;

- izostavljanje i pogrešnu upotrebu relativnih zamjenica;

- pogrešnu upotrebu povratnih glagola odnosno povratnih zamjenica;

- izostavljanje drugog dijela negacije.

U lokalne greške koje ne ruše strukturu rečenice možemo u ovom slučaju ubrojiti:

- povremeno nepreciznu upotrebu pomoćnog glagola u složenim glagolskim formama;

- pogrešnu upotrebu determinanata;

- pogrešnu upotrebu ili izostavljanje predloga;

- pogrešno elidovanje;

- odsustvo ili pretjeranu upotrebu kada je riječ o slaganju u rodu i broju u GN;

- pogrešan redosled riječi kod upotrebe priloga. 


\section{Zaključak}

Na osnovu prethodne analize, možemo da konstatujemo da su i na kraju procesa učenja uočena sva tri tipa grešaka: sistemske, transferne i univerzalne. Međutim, značajno je istaći da se produkcija studenata četvrte godine, pored manjeg broja grešaka, odlikuje većim prisutvom omaški dok su u produkciji studenata prve godine dominantne greške. Kod studenata na kraju obrazovnog ciklusa prisutne su omaške prilikom upotrebe pomoćnog glagola, upotrebe glagolskog načina subjunktiva, $\mathrm{i}$ dr.

Dakle, iako je došlo do značajnog napretka u učenju, prisustvo omaški i grešaka ukazuje na to da studenti još uvijek ne vladaju jezikom L2 na isti način kao i izvorni govornici odnosno da ga nijesu u potpunosti naučili. Takav zaključak u skladu je i sa poznatim stavovima da samo $5 \%$ ljudi uspije da dostigne takav nivo znanja L2.

Transferne greške i omaške prisutne su u značajnoj mjeri na nivou sintakse (u predloškoj kao i u glagolskoj sintagmi).

Kada je riječ o fonetskom jezičkom podsistemu, upoređivanjem jezičke produkcije studenata prve i četvrte godine, uočila sam da studenti četvrte godine rijetko prave greške prilikom diskriminacije fonema a to znači da su oni uspjeli da asimiliraju fonetski sistem francuskog jezika u svoja prethodna znanja i da su se u velikoj mjeri oslobodili uticaja L1. O tome svjedoči gotovo potpuno odsustvo transfernih grešaka u ovom jezičkom podsistemu. Pa ipak, omaške su još uvijek prisutne kod elidovanja i pogrešne percepcije odnosa između grafema i fonetskih riječi.

Međujezik je prisutan i u produkciji studenata završne godine studija što ukazuje na to da se on i dalje razvija a to znači da je proces učenja L2 u toku. Da li će se proces učenja L2 nastaviti, zavisiće od motivacije ${ }^{10}$ studenata odnosno od toga koje ciljeve žele da ostvare $u$ periodu nakon sticanja diplome.

Osim prethodno navedenih zaključaka, rezultati ove studije slučaja ukazuju i na potrebu veće izloženosti studenata prve godine jezičkim sadržajima (input) na francuskom jeziku u smislu koji im pripisuje S. Krašen (2019). Učenje L2 odvija se tokom izloženosti jeziku, spontano, a da toga nijesmo ni svjesni, kroz postepeno razumijevanje (comprehensiv input) onoga što čitamo ili slušamo (a ne kada govorimo ili pišemo).

10 R. Elis govori o sledećim vrstama motivacije - instrumental motivation, integrative motivation, resultative motivation, intrinsic motivation (1997, 7576). 
S. Krašen i B. Mason (2020) uvode hipotezu optimalnog jezičkog sadržaja u nastavi (optimal input) koji treba da ima četiri karakteristike, da bude: 1. Razumljiv ali ne i u potpunosti transparentan. 2. Izuzetno zanimljiv i uvjerljiv. 3. Bogat jezikom koji doprinosi spontanom razumijevanju poruke, priče ili teksta. Sama struktura jezika podstiče razumijevanje i sticanje novih jezičkih znanja. 4. Učenje jezika je postupan proces: uvijek kada naiđemo na novu riječ u kontekstu koji razumijemo, stičemo djeliće novih znanja. Stoga, optimalni input podrazumijeva mnogo raznovrsnih jezičkih sadržaja i brojne mogućnosti za učenje novog jezika.

Istraživanja su pokazala da optimal input ima za rezultat uspješnije učenje jezika a proces učenja i nastave postaje mnogo prijatniji i za studente i za nastavnike.

Postavlja se pitanje izbora odgovarajućeg jezičkog materijala pa Krašen ističe da to treba da budu kratke ali veoma zanimljive priče jer i djeca i odrasli obožavaju priče. Ovakav izbor materijala omogućio bi studentima da se toliko unesu u priču da zaborave da zapravo uče jezik. Više razumljivog jezičkog inputa poboljšava output odnosno produkciju. U našem konkretnom slučaju, problem odabira kratke, lagane, zanimljive literature na francuskom jeziku podrazumijevao bi bogat i osavremenjen bibliotečki fond ali i uključivanje studenata u izbor tekstova koje bi čitali odnosno slušali, u grupi i samostalno.

Pored navedenog, u cilju unaprijeđivanja procesa učenja za studente prve godine, smatram da bi u okviru naredne akreditacije studijskih programa trebalo povećati broj časova francuskog jezika sa aktuelnih $2 \mathrm{P}+6 \mathrm{~V}$ na $2 \mathrm{P}+8 \mathrm{~V}$. ${ }^{11}$ Povećavanje broja časova omogućilo bi da se više vremena posveti upravo samom procesu učenja i izloženosti jeziku kroz čitanje i slušanje. Pomenuti časovi vježbanja mogli bi da nose naziv: razumijevanje, čitanje, slušanje, ili dr.

Osim toga, ova studija slučaja pokazala je da u produkciji studenata prve godine značajno mjesto zauzimaju greške na nivou fonetskog podsistema. Da bi se poboljšalo učenje odnosno da bi se studentima pomoglo da lakše asimiliraju fonetski sistem francuskog jezika u jezička znanja koja već posjeduju, trebalo bi razmisliti o povećanju fonda časova iz fonetike ali i o razdvajanju časova fonetike i morfologije, disciplina koje se trenutno izučavaju u okviru jednog predmeta, Francuski jezik - Fonetika i morfologija, sa fondom časova $2 \mathrm{P}+2 \mathrm{~V}$ po semestru.

\footnotetext{
${ }^{11}$ Nekada su na sličnim studijskim programima postojala još 2 časa vježbi po semestru koja su podrazumijevala vježbe slušanja, govora, lektorske vježbe, i dr.
} 
Povećanje broja časova francuskog jezika na prvoj godini studija, novo koncipiranje silabusa, preispitivanje naziva kurseva i restrukturiranje pojedinih jezičkih disciplina, unaprijedili bi učenje L2 i otvorili nove mogućnosti za primjenu savremenih trendova u nastavi.

\section{Literatura}

Adjemian, Christian. „On the Nature od Interlanguage Systems." Language learning, 26 (2), 1976. 297-320.

Andersen, Roger. "Transfer to Somewhere." U. S. Gass \& L. Selinker (Eds.), Language transfer in language learning 1983. 177-201. Rowley, MA: Newbury House.

Burt, Marina and Carol Kiparsky. The Gooficon: A Repair Manual for English. Massachusetts:

Newbury House Publishers, 1972.

Corder, Steven Pit. "The significance of learner' errors.“ IRAL: International Review of Applied Linguistics in Language Teaching 5 (4), 1967. 161-171.

Corder, Steven Pit. Error analysis and Interlanguage. Oxford: Oxford University Press, 1981.

Cortés, Nuria Calvo. "Negative language transfer when learning Spanish as a foreign language." Interlinguistica, 16 (1), 2005. 237-248.

De Angelis, Gessica and Larry Selinker. „Interlanguage transfer and competing linguistic system in the multilingual mind." Kod: J. Cenoz, B. Hufeisen \& U. Jessner (Eds.), Cross-Linguistic Influens in Third Language Acquisition: Psycholinguistic Perspectives. Clevedon: Multilingual Matters, 2001. 42-58.

Dulay, Heidi, Marina Burt and Stephen Krashen. Language two. New York: Oxford University, 1982.

Edge, Julian. Mistakes and correction. London: Longman, 1989.

Ellis, Rod. Understanding Second Language Acquisition. Oxford: Oxford University Press, 1985.

Ellis, Rod. The Study of Second Language Acquisition. Oxford: Oxford University Press, 1994.

Ellis, Rod. Second Language Acquisition. Oxford: Oxford University Press, 1997.

Galligani, Stéphanie. „Réflexion autour du concept d'interlangue pour décrire des variétés non natives avancées en français. L'actualité des notions d'interlangue et d'interaction exolingue." Linx, Revue des linguistes de I'Université Paris Ouest Nanterre la Défense 49 | 2003. 141-152. Editeur: Open Edition Journals Presses Universitaires de Nanterre. DOI: 10/4000/linx.562 ISSN: 2118-9692. https://doi.org/10.4000/linx.562 (sajt posjećen 27. 7. 2020.)

James, Carl. Errors in Language Learning and Use: Exploring Error Analysis. Harlow, Essex: Addison Wesley Longman Limited, 1998.

Kellerman, Eric. „Crosslinguistic influence: Transfer to Nowhere?.“ Annual Review of Applied Linguistics, 15, 1995. 125-150.

Kellerman, Eric and Michael Sharwood-Smith. Crosslinguistic influence in second language acquisition. London: Pearson College Division, 1986. 
Krashen, Stephen. Second Language Acquisition and Second Language Learning. University of Southern California: Pergamon, Press Inc, 1981.

Krashen, Stephen. Principles and Practice in Second Language Acquisition. Oxford: Pergamon Press, 1982.

Lado, Robert. Linguistics across Cultures. Ann Arbor: University of Michigan Press, 1957.

Larsen-Freman, Diane and Michael H Long. An Introduction to Second Language Acquisition Research. London: Longman, 1991.

Munoz, Carmen. Apprender idiomas. Barcelona: Paidos, 2002.

Nemser, William. „Approximative Systems of Foreign Language Learners.“ IRAL: International Review of Applied Linguistics in Language Teaching 9 (2), 1971. 115-123.

Odlin, Terence. Language transfer. Cross-linguistic influence in language learning. Cambridge: Cambridge University Press, 1989.

Richards, Jack. Error Analysis: Perspectives on Second Language Acquisition. Kod: J.C. Richards (Eds.), A non-contrastive approach to error analysis (172-188). London: Longman, 1974.

Selinker, Larry. „Interlanguage.“ International Review of Applied Linguistics X-3, 1972. 209-231. DOI: 10.1515/iral.1972.10.1-4.209

Selinker, Larry, M Swain and G Dumas. „The interlanguage hypothesis extended to children." Language Learning, 25-1, 1975. 139-152.

Selinker, Larry. Rediscovering Interlanguage. London: Longman, 1992.

Stanković, Svetlana. „O pojmu i razvoju kontrastivne analize jezika.“ Zbornik radova Filozofskog fakulteta u Prištini, 39, 2009. 65-77.

Thornbury, Scott. An A-Z of ELT. A dictionnary of terms and concepts used in English language teaching. Oxford: Macmillan Books for Teachers, 2010.

Vogel, Klaus. L'interlangue: la langue de l'apprenant. Toulouse: Presses Universitaires du Mirail, 1995.

Weinreich, Uriel. Languages in Contact. New York: Linguistic Circle of New York, 1953.

Weinreich, Uriel. Languages in Contact: Findings and Problems. The Hague: Mouton, 1968.

Doktorska teza:

Vujović, N. Marija. Doktorska disertacija: Problemi u procesu učenja izazvani negativnim transferom u pisanoj produkciji srpskih studenata koji uče dva tipološki srodna jezika - slučaj italijanskog kao L2 i španskog kao L3. Beograd: Univerzitet u Beogradu, Filološki fakultet, 2019. http://nardus.mpn.gov.rs/bitstream/handle/123456789/11859/Disertaci ja. pdf?sequence=6\&isAllowed=y (sajt je posjećen 28. 8. 2020.)

Web adrese:

Krashen, Stephen. „Optimal Input." (26.12.2019.) Web: https://www.youtube.com/watch?v=S j4JELf8DA, 2. 09. 2020. 
Krashen, Stephen and Beniko Mason. "The Optimal Input Hypothesis: Not All Comprehensible Input is of Equal Value." CATESOL Newsletter, pages 1-2. May 2020.

http://beniko-mason.net/content/articles/2020-the-optimal-inputhypothesis.pdf. 19 decembar 2020.

Pallotti, Gabriele. Interlingua e analisi degli errori. 2007. Web: http://www.salainsegnanti.it/documenti/materialeinsegnati/Interlingua\%20e\%20analisi\%20degli\%20errori\%20\%20Gabriele\%20Pallotti\%20\%20MIUR.pdf 1 novembar 2020.

Stockwell, Robert P and and J Donald Bowen. "Sound system in conflict: $a$ hierarchy of difficulty." 1965. https://www.scribd.com/document/137955021/Stockwell-Bowen-1965. 1 novembar 2020.

Onlajn enciklopedija: „Interlanguage“. Wikipedia. Web: https://en.wikipedia.org/wiki/Interlanguage. 29 jul 2020.

\section{L'APPRENTISSAGE DU FRANÇAIS (L2) ET L'INTERLANGUE - UNE ÉTUDE DE CAS}

Au cours du processus d'apprentissage de L2, les étudiants se créent système de règles abstraites qui assurenet la compréhension et la production en L2. Cette langue abstraite est considérée comme une grammaire mentale (Elis 1997,33 ) et s'appelle interlangue/Interlanguage (Selinker 1972; 1975).

L'interlangue est une phase dans le processus d'apprentissage de $L 2$ qui aide les apprenants à restructurer mentalement les nouvelles connaissances, formes, structures et fonctions qu'ils sont en train d'acquérir. La langue que les apprenants utilisent n'est pas seulement le résultat des différences entre les langues qu'ils connaissent déjà et celle qu'ils apprennent, la langue cible, mais c'est un système linguistique à part entière ayant ses propres règles. Les structures qui émergent dans l'interlangue ne sont pas arbitraires.

Dans cet article, mon objectif est de décrire les caractéristiques de la langue (L2) parlée par les étudiants de français en première et en dernière année d'études, d'expliquer ce que cela dit sur la nature de leurs connaissances et en quoi leur interlangue diffère de la langue des locuteurs natifs du français standard.

Pour atteindre cet objectif, dans le cadre d'une étude de cas, j'analyserai comment les étudiants développent la capacité de produire certaines structures grammaticales. Je décrirai les erreurs dans leur production, je les expliquerai et je les évaluerai en suivant la méthodologie de la théorie de l'apprentissage de L2 - SLA (Elis 1997, 16-23).

Je définirai les éléments qui distinguent l'interlangue des étudiants en première et celle des étudiants en quatrième année afin de comprendre comment elles se développent.

Les résultats de la présente recherche seraient appliqués à la redéfinition des objectifs et des activités d'enseignement de français. 
Mots clés: l'apprentissage de L2, l'analyse des erreurs, l'interlangue, le continuum et l'interlangue, erreurs vs. fautes. 